Vozes da cultura italiana 


\title{
Como entrou \\ e como finalmente saiu \\ de cena a democracia grega
}

\author{
LUCIANO CANFORA
}

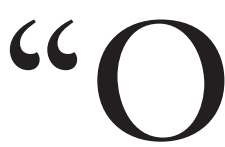
POvo É, por vontade de Deus, a fonte de todo justo poder. Os Comuns da Inglaterra, reunidos no Parlamento, escolhidos pelo povo e representando-o, são o supremo poder desta nação. Qualquer coisa estabelecida ou declarada pelos Comuns no Parlamento reunido tem força de lei, e o povo da nação como um todo tem que respeitá-la, mesmo sem o consentimento do rei e da Câmara dos Lordes." Em 4 de janeiro de 1649, o Rump Parliament (o "Parlamento manco" ou "os restos do Parlamento") - isto é, o que sobrou do Longo Parlamento após a "mutilação" (prisão dos noventa deputados da ala intransigente presbiteriana) infligida pela "Purga de Pride" (6 de dezembro de 1648) - sancionou esse princípio, que pode ser considerado o ponto de chegada e, ao mesmo tempo, a formulação mais avançada que a primeira Revolução inglesa produziu. O que está escrito naquela deliberação é o sumo e a síntese dos intensos debates travados em Putney, na igreja presbiteriana do pequeno subúrbio de Londres no fim de outubro de 1647: debates que viram a contraposição de todas as vozes, de todos os grupos sociais. A deliberação de 4 de janeiro sancionava também a vitória da ala mais avançada que, naqueles debates, rigorosamente não-acadêmicos, decerto não se deixara atemorizar.

O que impressiona, folheando os registros daquelas discussões, ${ }^{1}$ é não só a evidente matriz religiosa e "reformada", mas também a falta de referências a tradições estranhas à Bíblia e à história cristã. Para os homens de Cromwell, o Êxodo narra a futura libertação: a Escritura, mais que narrar a história passada, anuncia o futuro. Michael Walzer fala, a esse respeito, em "Revolução dos Santos".

Desde o começo, a Revolução inglesa se configurou como um coerente desenvolvimento, no plano diretamente político, da ruptura antiautoritária representada pela Reforma. O aspecto religioso é preponderante, nos oito longuíssimos e atormentados anos que vão de 1641 (aprovação do "Grande Protesto" por parte do Parlamento) a 1649, não apenas nos textos oficiais e nos documentos, mas também na amplíssima publicística que acompanha, como pano de fundo, todas as suas vicissitudes. Exemplar, sob esse aspecto, o próprio texto do "Grande Protesto". Aí as raízes do "mal” são divididas em partes iguais, entre os "papistas jesuíticos", voltados a subverter a religião anglicana, e "os bispos [anglicanos] e a parte corrupta do clero, que alimentam o forma- 
lismo e a superstição como efeitos naturais e sustentáculos mais prováveis da sua tirania". Resultado da Revolução foi justamente a eliminação da estrutura episcopal da igreja anglicana. A batalha das idéias era batalha no campo religioso, e os conceitos utilizados, os mitos de referência, eram extraídos precisamente da Escritura e do conflito começado no século anterior com a "rebelião" luterana contra Roma.

Aliás, sem dúvida, a igreja anglicana, fortemente hierarquizada e orientada a voltar para uma religião decididamente ritualista, era o esteio principal do absolutismo monárquico (daqui a falta de fundamento substancial na acusação dirigida a Carlos I de querer restaurar o "papismo jesuíta"). Na vertente oposta, os presbiterianos e os puritanos eram muito conscientes do nexo, inerente à sua ação e sua propaganda, entre afirmação religiosa e reivindicação do princípio de "soberania popular" ("por vontade de Deus o povo é a fonte do justo poder").

Podemos citar um trecho qualquer dos debates de Putney, para perceber o fenômeno diretamente. Na discussão de 29 de outubro, Rainsborough replica com firmeza aos "Grandes": "Não acho nenhuma passagem da Lei de Deus que afirme que um Lorde deva escolher vinte deputados, um gentleman somente dois, e um pobre nenhum". ${ }^{3}$

É preciso considerar também um outro elemento constitutivo da mentalidade dos "niveladores": a reivindicação, por parte deles, de um fator "étnico". Antes de Guilherme o Conquistador - é essa a tese sustentada por Henry Ireton, cunhado de Cromwell, na segunda das jornadas de Putney -, existia entre os anglo-saxões uma constituição antiqüíssima baseada na liberdade e na igualdade: os "direitos inatos" dos ingleses derivam dessa "constituição"; esses direitos teriam sido violados pelo predomínio dos reis normandos, até o reinado de Carlos I. Essa visão da história remota e recente da Inglaterra leva, graças à elementar dialética de Ireton, a bloquear a instância radical de um verdadeiro sufrágio universal. O equívoco está na frase que o próprio expoente dos niveladores pronuncia: "Nós julgamos que todos aqueles habitantes que não têm o seu direito inato comprometido devem ter um voto igual nas eleições". A expressão "direito inato", conjugada com a teoria da antiqüíssima liberdade dos anglo-saxões, se torna a base para sancionar que, em todo caso, numa comunidade, nem todos são necessariamente iguais em relação ao direito de voto; e que esse direito está ligado à origem "étnica".

Nem uma palavra sobre "os outros". A liberdade política e a maior igualdade que esses revolucionários pedem colocam-se entre dois pólos: de um lado, o fundamento ideológico constituído pela Bíblia; de outro, a "nação", a "estirpe".

A evocação bíblica está muito presente também na linguagem e na retórica política dos colonos da América:

Porque aprouve a Deus todo poderoso, por sábia determinação da sua divina providência, ordenar e dispor as coisas de forma que nos reuníssemos para viver nas proximidades do Rio Connecticut, nos juntássemos e associássemos para formarmos um único público Estado ou Commonwealth, para manter- 
mos e preservarmos a liberdade e a pureza do Evangelho [...] Nas eleições dos juízes tomarão parte todos aqueles que são considerados cidadãos, que juraram fidelidade, e que residem nesta jurisdição, reconhecidos como residentes pela maioria dos habitantes da cidade em que moram etc. [...]

Tendo empreendido uma viagem para fundar a primeira Colônia na região setentrional da Virgínia, para maior glória de Deus e para a difusão da Fé Cristã etc.

O estilo desses documentos, redigidos na primeira metade do século XVII, ecoa ainda, um século e meio mais tarde, na Declaração de Independência, cujo texto final é em boa parte baseado no rascunho preparado por Thomas Jefferson (julho de 1776). “Quando, no decorrer dos eventos humanos, faz-se necessário para um povo desatar os vínculos que o tinham ligado a um outro e assumir entre as outras potências da terra aquele lugar distinto e igual a que tem direito por Lei natural e divina..."; e pouco depois: "todos os homens foram criados iguais, foram dotados pelo seu Criador de alguns direitos inalienáveis etc.”. ${ }^{4}$

Além dessa ênfase "bíblica”, pesados condicionamentos concretos ofuscavam o quadro. Num recente ensaio, significativamente intitulado "Até que ponto é democrática a Constituição americana?”, Robert Dahl recordou que, na sua primeira redação (1787), a Constituição americana aceitava o instituto da escravidão e até "incorporava, entre seus princípios, a repugnante legislação contra os escravos fugitivos”. Além disso, ela deixava intactas as restrições ao direito de voto estabelecidas por cada Estado, que excluíam os afro-americanos, as mulheres e os nativos. ${ }^{5}$

Mais uma vez o "convidado de pedra" dessas grandiloqüentes cartas é a instituição da escravidão. Mais uma vez, assim como no caso inglês, os dois "pólos" de movimento são o fundamento bíblico e a ancoragem na estirpe. Jefferson esforçou-se por fazer valer, em Paris, suas simpatias enciclopedistas, mas não pôde evitar o constrangimento de enfrentar as críticas de seus amigos e interlocutores franceses - sua principal fonte de inspiração - em relação à persistência, em regime livre e republicano, da instituição da escravidão. Como governador da Virgínia, ele fez aprovar uma lei que proibia naquele Estado a posterior importação de escravos, o que não o impedia a si próprio de tê-los, ainda que tratados humanamente, na fazenda-modelo de Monticello

Na sessão do 16 pluvioso do ano II (4 de fevereiro de 1794), a Convenção Nacional, por iniciativa do cidadão Louis-Pierre Dufay de la Tour (um dos três deputados eleitos em Santo Domingo que acabara de chegar a Paris no dia anterior, depois de uma viagem aventurosa e não desprovida de lados obscuros, e que foi logo admitido à Convenção), pediu e obteve - naquela memorável sessão - um decreto a favor "dos nossos irmãos das colônias". O apego deles à República - ele observou - é tão forte que já se faz necessária uma medida "que devolva a tranqüilidade ao Novo Mundo, garantindo aos negros que o habitam - e que merecem ser franceses! - as vantagens da nossa Constituição e todos os direitos inerentes à liberdade e à igualdade". 
No longuíssimo discurso que Dufay pronunciou, e que difundiu imediatamente com uma brochure "imprimée par ordre de la Convention", ressalta um episódio, evocado com ênfase pelo recém-deputado: uma delegação de escravos negros apresenta-se aos franceses, no meio do conflito contra ingleses e espanhóis, e pede a liberdade em nome da Declaração dos Direitos do Homem ("Nous sommes nègres, Français, nous allons combattre pour la France: mais pour récompense nous demandons la liberté; ils ajoutèrent: 'les Droits de l'Homme"). E analogamente, no curso da discussão, o deputado da Sarthe, René Levasseur, fiel robespierrista e áspero adversário dos termidorianos (e que por ordem deles sofrerá dura prisão por ter feito aprovar naquele 16 pluvioso a abolição da escravidão), diz, tomando a palavra logo depois do Dufay:

Eu peço que a Convenção, não por um extemporâneo movimento de entusiasmo mas em homenagem aos princípios da justiça, fiel à Declaração dos Direitos do Homem, decrete que a partir de hoje a escravidão seja abolida em todo o território da República. Santo Domingo faz parte deste território, e, todavia, nós temos escravos em Santo Domingo. Eu peço então que todos os homens sejam livres, sem distinção de cor.

Em apoio a Levasseur intervém o deputado Jean-François Delacroix (que pouco tempo depois foi condenado no feroz processo contra os dantonistas). Ele começa pertinentemente com uma menção à insuficiência, ou pelo menos ao caráter não-explícito, das cartas constitucionais até então elaboradas:

Enquanto trabalhávamos na Constituição do povo francês nós não temos, no entanto, levado o nosso olhar aos desventurados homens de cor. A posteridade terá então uma grande reprovação a nos fazer sob esse aspecto, porém temos que reparar essa injustiça. Inutilmente deliberamos que nenhum direito feudal será reclamado no território da República francesa. Vocês acabaram de ouvir de um de nossos colegas que existem ainda escravos nas nossas colônias! É hora de nos elevarmos nós mesmos à altura dos princípios da liberdade e da igualdade. Não será suficiente responder que não admitimos a escravidão em solo francês: não é porventura verdade que os homens de cor são escravos nas nossas colônias? Então temos que proclamar a liberdade dos homens de cor. Realizando esse ato de justiça, vocês darão um exemplo importante aos homens de cor que são escravos nas colônias inglesas e espanholas. Os homens de cor, exatamente como nós, quiseram quebrar suas correntes. Quisemos quebrar as nossas, não quisemos submeter-nos ao jugo de nenhum patrão: concedamo-lhes o mesmo dom.

A nova intervenção de Levasseur é significativa também no plano léxico: "Se fosse possível" - ele diz intervindo brevemente - "mostrar à Convenção o quadro doloroso dos males inerentes à escravidão, eu vos faria estremecer, representando-vos a opressão [o termo utilizado é "l'aristocratie"] exercida nas nossas colônias por alguns brancos".

Delacroix toma a palavra oportunamente e com eficácia: "Presidente! Não podeis tolerar que a Convenção se desonre prolongando além do aceitável uma discussão sobre este assunto!”. E propõe imediatamente uma minuta de deli- 
beração: "A Convenção nacional decreta que a escravidão seja abolida em toda extensão do território da República. Em razão disso, todos os homens, sem distinção de cor, gozarão dos direitos de cidadãos franceses".

A essa altura, alguns deputados se apresentam com um reparo um pouco ambíguo, e potencialmente insidioso: "Evitemos que a própria palavra escravidão suje um decreto da Convenção: tanto mais que a liberdade é um direito natural". Em resumo, era um convite a não redigir nenhum específico decreto de abolição da escravidão, argumentando especiosamente que tal abolição estava "implícita" no princípio geral: já está reconhecido que a liberdade é um direito natural. Decisiva a intervenção do abade Grégoire, que secamente dissipa o sofístico escamotage: "É necessário" - diz - "que a palavra escravidão seja colocada, senão futuramente alguém poderá afirmar que vocês queriam dizer outra coisa; porém todos vocês querem que a escravidão desapareça".

A assembléia se levanta, em pé, e por aclamação aprova o texto apresentado por Delacroix. O presidente - que naquele dia era Marc Vadier, personagem decerto desagradável, mas que pagou pessoalmente também por sua adesão à "conspiração" de Babeuf - proclama formal e solenemente a abolição da escravidão, enquanto, entre os gritos "Viva a República, Viva a Montanha!", os três deputados que provinham das colônias são abraçados, "étroitement serres" - diz o cronista parlamentar - "dans les bras de leurs collègues". ${ }^{6}$

Onde o contraste com a obstinada defesa da escravatura por parte da liberal Inglaterra era mais imediatamente evidente, isto é, nas Antilhas, a ação libertadora começada pela Convenção com o decreto do 16 pluvioso resultava logo explosiva. Assiste-se ao choque campal entre duas concepções de liberdade: a dos liberais ingleses que defendem, de armas na mão, a instituição da escravidão, e a da Convenção da Montanha que se compromete - lamentando tê-lo feito com atraso - a "elevar-se à altura do princípio de liberdade e de igualdade", abolindo explicitamente a dependência pessoal dos negros. A insistência na cor da pele é capital: na serenidade dos liberais ingleses que restabelecem a escravidão assim que conseguem tomar posse, nas Antilhas, de uma colônia ex-francesa, pesa o fator racista, a visão do negro como não-homem, como homem inferior.

Henri Bangou, o maior historiador negro de Guadalupe, narrou pertinentemente o fato na sua História de Guadalupe. No mesmo 4 de fevereiro de 1794, em que a Convenção vota a ordem do dia de Delacroix, a frota inglesa é avistada perto do litoral da Martinica. Em 24 de março, os ingleses ocupam a Martinica e pouco depois desembarcam em Guadalupe, chamados pelos "Grandes brancos" (que se prontificam a assinar um tratado com Londres), debaixo da substancial indiferença dos "Pequenos brancos". Os brancos, também os "republicanos", adaptam-se e consideram que "l'intention de la République n'est pas de régner sur des cendres et des débris" [!]. No que diz respeito à administração, todo o aparato do Ancien Régime é restaurado, e é confirmada a validade da instituição da escravidão, que aliás nem foi possível abolir, dada a concomitância entre o voto na Convenção e o ataque inglês às duas ilhas das pequenas Antilhas. 


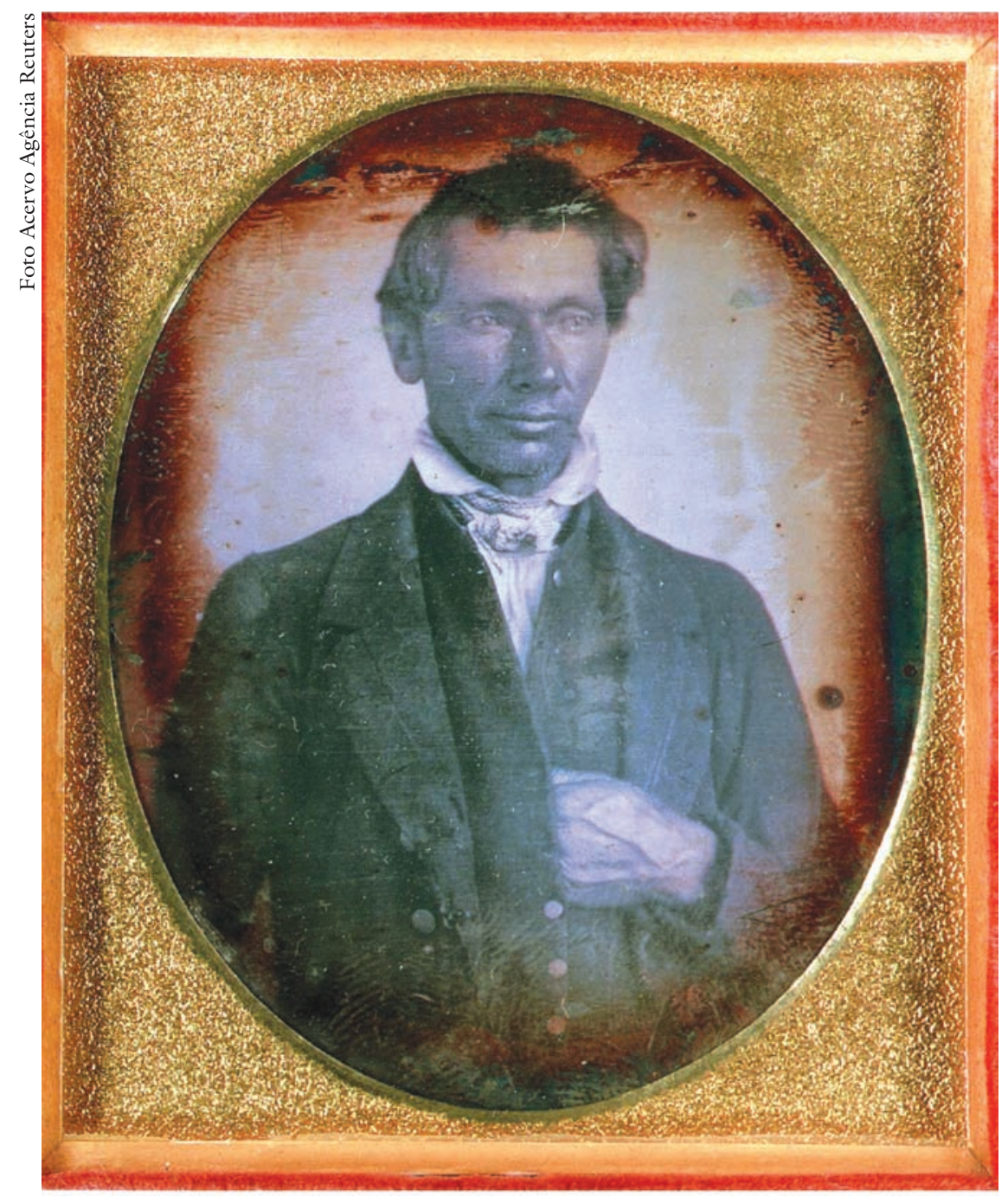

Daguerriótipo do presidente dos EUA Abrabam Lincoln (1809-1865) aos 34 anos de idade.

O promotor da luta contra os ocupantes ingleses e artífice da libertação dos escravos da ilha - depois de uma guerrilha que durou anos e se concluiu com a volta à França republicana e abolicionista - foi Victor Hugues, que já fora delegado do Ministério Público no tribunal revolucionário de Rochefort e de Brest, e depois (no começo de 1794) comissário nas Ilhas de Barlavento. Ele deu o que fazer aos escravistas ingleses, obrigando-os a fazer-se ao largo e conquistando outras ilhas, por exemplo Marie-Galante. Os ex-escravos negros foram o nervo do seu exército.

Como foi possível que a partir das proclamações de “direitos” das revoluções inglesas e da Revolução americana não se desprendesse uma visão, e uma praxe, que colocassem em discussão a escravidão? Por que aqueles defensores de "direitos" e "liberdades" acharam normal continuar a conviver com a escravidão nas suas colônias (nas dos outros, quando as ocuparam) ou até na sua própria casa, como é o caso dos Estados Unidos? 
Um razão de fato, e econômica, tem que ser colocada certamente em primeiro plano. Em relação à realidade dos Estados Unidos, Henri Bangou escreve, não sem razão, que o caso norte-americano é o exemplo mais interessante da "relatividade histórica, econômica e política da noção de liberdade, e também da mistificação a que ela pode ser submetida". A guerra conduzida contra a Inglaterra culminou na proclamação da independência, mas a prova mais clara da mutilação da noção de liberdade, com a sua aplicação a favor de uma classe, foi precisamente a permanência, nesse novo Estado "livre", de uma instituição que negava a liberdade, como é de fato a escravidão. "O verdadeiro motor da história e das instituições quer políticas quer sociais - isto é a economia, e não o espírito, ou a razão ou algum outro demiurgo - não exigia ainda o desaparecimento do modo de produção escravista do horizonte dos Estados Unidos", escreve ironicamente Bangou, e observa pouco depois que não foi necessário muito esforço para conciliar as posições de todos os $\mathbf{5 6}$ delegados incumbidos de dar ao novo Estado um corpo de leis: "Tampouco permaneceu qualquer vestígio da incoerência do período da guerra [contra os Ingleses], quando se alistavam os negros com a promessa da liberdade, e ao mesmo tempo prometiam-se escravos negros aos brancos em troca de colaboração!"?

Não é, porém, inteiramente verdade que outros fatores não tenham exercido influência. O cunho fortemente bíblico-protestante teve seu papel. Entre os alicerces mentais desses homens, sobressaía o Novo Testamento que tinha - para a axiologia deles - o mesmo peso, e talvez mais, do que os gregos e romanos para os revolucionários franceses. A Escritura contém uma boa justificação para a manutenção de fato da escravidão.

Diz o apóstolo Paulo na Carta aos Efésios (6,5-9):

Escravos, obedeçam a seus senhores, com temor e tremor, com simplicidade de coração, como obedecem a Cristo; sirvam de bom grado, como se tratasse do Senhor e não de homens, sabendo bem que cada um, escravo ou livre, do bem que tiver feito receberá a recompensa do Senhor. E vocês senhores tratem seus escravos com a mesma disposição: sabendo bem que o Senhor - seu e deles - está no céu, e que Ele não faz distinção de pessoas.

E quando um escravo, Onésimo, que pertencia a um patrão também cristão, Filêmon, fugiu e chegou a Roma, onde entrou em contato com Paulo, esse o mandou de volta a Filêmon, na longínqua vila frígia de Colosse, com um bilhete de acompanhamento que - muito significativamente - faz parte da coletânea de cartas paulinas. É uma obra-prima de habilidade, que visa aplacar o patrão perante um crime contra a propriedade, considerado dos mais graves:

Eu o mandei de volta para ti: ele, que é como se fosse meu próprio coração. Gostaria que ele tivesse ficado comigo enquanto estou preso por causa do Evangelho: porém não quis fazer nada sem o teu consentimento; não quero que tua bondade seja forçada, mas espontânea. Talvez por isso ele tenha sido afastado por algum tempo de ti: para que o tenhas de volta para sempre. Mas não mais como escravo, mas muito mais do que escravo: como um irmão. (A Filêmon, 12-18) 
Escrevendo aos gálatas, Paulo repete que já "não há mais nem judeu nem grego, nem homem livre nem escravo, nem homem nem mulher" $(3,28)$, mas na primeira carta aos coríntios avisa: "Cada um permaneça na condição que o Senhor lhe destinou" $(7,20)$. Um equilíbrio instável, porém produtivo do ponto de vista prático - todos permaneçam no seu lugar, os escravos fugitivos voltem a submeter-se aos donos, que porém têm que tratá-los com humanidade -, ficando estabelecido que, alhures e em relação ao além, essas distinções não contam. Fica claro porque inicialmente os constituintes da Virgínia pensaram até em redigir um conjunto de normas contra os escravos fugitivos.

Entrando em contato com a realidade do domínio colonial, alguns jesuítas coerentes e rebeldes tinham, porém, sacudido - em nome do Evangelho e expondo-se ao desmentido e à acusação de heresia - a base das desigualdades sociais e sobretudo da escravidão: que se pense na lição subversiva do Padre Vieira, que ecoa no apelo, nos dias de hoje, de Rigoberta Menchú, guatemalteca, ao valor revolucionário da Bíblia totalmente esquecido pelos europeus. ${ }^{8}$ Mas esse radicalismo cristão, que emergia do mundo que os rebeldes ingleses tinham rotulado de "papista", não estava presente e não era apreciado no mundo dos reformados, ou dos dissidentes da Reforma que constituíam a intelligentsija diretiva das revoluções nascidas no mundo anglo-saxão. A partir de uma "concepção do mundo" com base bíblica, não se chegava à afirmação da liberdade de todos aqui e agora, na visível e concreta sociedade presente.

Na sessão da Convenção do 16 pluvioso - em que não faltaram cenas muito patéticas, como o desmaio patriótico da cidadã negra "que acompanha diariamente as sessões e apoiou desde o começo todos os movimentos revolucionários", para usar as palavras do deputado Cambon -, Danton se levantara também para falar, principalmente com o objetivo de fazer que se delegasse aos dois comitês, o de saúde pública e o das colônias, a efetivação concreta do decreto abolicionista. Ele começara com uma consideração muito significativa: "Até hoje nós afirmamos o princípio de liberdade à maneira dos egoístas, somente para nós. É com a decisão de hoje que proclamamos a liberdade universal, perante o universo, e as gerações futuras encontrarão sua glória neste decreto". E continuou: "Trabalhamos para as gerações futuras: damos a liberdade às colônias; depois de hoje o Inglês morreu (aplausos). Levada a liberdade para o Novo Mundo, ela dará lá frutos abundantes, e lá fincará raízes profundas". (Danton se expressa como se no "Novo Mundo" a "liberdade" jamais tivesse existido: o que implica também um juízo sobre os Estados Unidos.)

É sobre esse conceito de liberdade "egoística" que precisamos nos deter. Sabe-se que a crítica movida ao modelo antigo (da Idade Clássica) que está no centro da ideologia revolucionária, e jacobina em especial, é justamente que a liberdade da Antigüidade Clássica era por excelência uma liberdade "egoística", destinada a poucos, em todo caso a uma minoria.

Entre março e abril de 1795, no ano III da República, saía em Paris uma volumosa biografia e bibliografia de Xenofonte: Vie de Xénophon, suivie d'un 
extrait historique et raisonné de ses ouvrages, escrita pelo cidadão Fortia, um exnobre, agora republicano, especialmente escrupuloso na compilação mensal das certidões de civismo. Esse livro, que tem uma longa história editorial, começa com algumas frases de certeiro sabor "patriótico", como se dizia naquela época: "A liberdade e a filosofia são a nossa senha [cri de ralliement]". E segue dessa forma um pouco desajeitada: como Xenofonte era um filósofo, e ainda por cima do tempo em que a Grécia era um país livre, melhor tema não se poderia achar. Já que na época se publicava com extrema parcimônia - a República estava cercada pela guerra externa das potências aliadas, ferida internamente pela rebelião vandeana, devastada economicamente pela invasão de notas falsificadas chegadas da Inglaterra -, e principalmente se dava prioridade a livros de utilidade e de relevância pedagógica, é mesmo significativo que o bom cidadão Fortia, apesar de ser um ex-nobre e obrigado por isso a morar fora de Paris conforme aos "decretos de germinal" (fim de abril de 1794), conseguisse não só escrever, mas também enviar para tipografia e fazer imprimir o seu Xenofonte. A obra gravitava na órbita de Jean-Baptiste Gail, ex-abade, agora republicano e professor no Collège de France no lugar de um "suspeito" que foi parar na prisão.

Esses esclarecimentos ajudam a entender que a obra é "maquiada" como fielmente republicana para escapar à censura, mas assim não é no conteúdo. É preciso ler muitas páginas para perceber isso. Quando se chega ao Hiero, pequeno ensaio sobre a tirania, repara-se como, após muitas tortuosidades, Fortia utiliza o autor grego para mover uma crítica à "tirania popular" exercida em nome da igualdade (não sem pontuais alfinetadas contra Rousseau). E quando se chega à Constituição dos Atenienses (aquele texto de dúbia autoria que, na época de Fortia, todos tinham certeza que fosse obra de Xenofonte), o ataque à democracia se torna mais agudo.

A idéia é de apresentar toda a matéria como obra do abbé Arnaud (o que não deixa de ser verdade: trata-se de um quase-plágio), cuja paráfrase do livrinho de Xenofonte é proposta de novo porque "atualmente é uma raridade". Claro, promete o autor, atenuarei algumas expressões demasiadamente monárquicas (de Arnaud), mas manterei muitas delas, "que caracterizam Xenofonte, cujas idéias não eram sempre republicanas [sic! ], e que então é preciso aceitar pelo que é" (p.39l). Segue uma paráfrase de Arnaud sobre o ataque de Xenofonte aos defeitos da ordem democrática ateniense. Obviamente o leitor vai se perguntar o que aconteceu com as premissas iniciais (liberté et philosophie) que determinaram a escolha de tratar de Xenofonte. Mas é sutil também a escolha de tomar Arnaud como intérprete (uma maneira confortável para não dizer em primeira pessoa as mesmas coisas), enquanto outros intérpretes, mesmo que sem razão, realizavam uma oposta leitura do opúsculo: como uma patriótica defesa de Atenas. ${ }^{9}$ Concluída a paráfrase do que foi dito por Arnaud (que não deixara de lembrar que toda a tradição filosófica ateniense a partir de Sócrates hostilizara a democracia), volta-se a Xenofonte: 
Essas foram as reflexões do abbé Arnaud sobre os escritos de Xenofonte. Eu me manterei, porém, nos limites do meu assunto e evitarei qualquer reflexão política sobre os princípios afirmados pelos três grandes filósofos gregos. Limitarme-ei a uma observação puramente histórica, apta a opor-se ao efeito de uma opinião tão digna de grande consideração como a que Arnaud extraiu daqueles três profundos conhecedores do coração humano. Minha observação então é a seguinte: aqueles três grandes pensadores podiam julgar a liberdade só na forma em que ela se apresentava aos seus olhos, isto é, manchada pela presença da escravidão. Na época, a escravidão estava por toda a parte ao lado da liberdade. De fato todas as nações antigas possuíam uma enorme quantidade de escravos, independentemente da sua forma de governo. E essa junção monstruosa - independente da forma de governo vigente - não ofereceu em nenhuma das antigas nações o belo espetáculo de uma verdadeira liberdade.

O escritor naïf, propositalmente banal na maioria de seus escritos, aqui assume uma singular densidade e força, numa das mais modernas análises do entrelaçamento inquietante liberdade/escravidão no mundo grego (e ele vai muito além das generalizações de Rousseau, Contrato social, III, 15). O conceito principal que ele quer focalizar é a drástica avaliação limitativa de todas as repúblicas antigas. Mas ele chega a essa conclusão de forma tortuosa: evoca um antidemocrático exaltador das reservas dos "socráticos" sobre a democracia; declara sua intenção de manter distância dele; mas não para defender as antigas democracias, e sim para liquidá-las como falsas democracias! E o argumentochave para essa finalidade é a "mancha" da escravidão. Sobre ela refletiu longamente, e concluiu muito modernamente que em todos os aspectos da vida antiga a escravidão estava presente (uma formulação que aparece em alguns dos mais brilhantes ensaios de Moses Finley sobre o assunto), que liberdade e escravidão eram, na sociedade antiga, inextricáveis; e que isso tornava irrelevante a diferença tipológica entre as várias formas de governo. O conceito de inextricabilidade, muito justo e moderno, é expresso com a fórmula "assemblage monstruenx". A conclusão é definitiva: em nenhuma parte do mundo clássico foi alguma vez oferecido "le beau spectacle d'une véritable liberté".

Aqueles eram, contudo, os modelos, os grandes modelos dos novos republicanos, obsessivamente repropostos.

Poucos dias antes, ou talvez nos mesmos dias em que aparecia em Paris este livro singular, Constantin-François Volney, historiador e antropólogo já de uma certa idade, que acabava de assumir uma cadeira na recém-nascida École Normale Supérieure, concluía sua quinta aula ( 3 germinal ano III= 23 de março de 1795 ) com uma veemente declaração sobre este tema:

Censurávamos nossos antepassados pela adoração supersticiosa dos judeus, e caímos numa adoração não menos supersticiosa dos gregos e romanos! Os nossos antepassados juravam sobre a Bíblia e Jerusalém; uma nova seita [e se refere obviamente aos recém-derrotados jacobinos] jurou sobre Esparta, Atenas e Tito Lívio. [E essa crítica tem como alvo a idéia errada que essa nova "seita" tinha sobre a realidade social antiga.] O que é singular neste novo tipo de religião é 
que seus apóstolos não tiveram uma visão apropriada da doutrina que pregavam, e que os modelos que nos propuseram são diametralmente contrários às suas declarações e intenções. Exaltaram a liberdade de Roma e da Grécia, e nos esconderam que em Esparta uma aristocracia de 30 mil nobres mantinha, sob um horrível jugo, 600 mil escravos; que para evitar o crescimento numérico deste tipo de negros, os jovens Lacedemônios saíam à caça de hilotas, como bichos selvagens; que em Atenas, este templo de todas as liberdades, para cada pessoa de condição livre havia quatro escravos; que não havia lar, em que o regime despótico dos nossos colonos da América não fosse exercido por esses presumidos democratas; que, numa população de cerca de cinco milhões de pessoas que povoavam a Grécia inteira, mais de três milhões e quinhentos mil eram escravos. ${ }^{10}$

Volney virava pelo avesso essa imagem "libertadora" da democracia antiga, recolocando-a na sua essencial dimensão de democracia para uma élite; a élite numericamente ampla, é verdade, mas restrita em comparação com as massas de escravos, dos cidadãos de pleno direito, dos "livres e iguais".

Mencionando os "nossos colonos da América", porém, Volney se alinhava sem dúvida - numa atitude muito digna - com a abolição estabelecida no ano anterior pela Convenção, e que Bonaparte - como veremos -, resolverá suprimir, restabelecendo a escravidão colonial e chegando a uma ruptura com Volney sobre essa questão.

Quanto, porém, à concepção realista do lugar embaraçoso da escravidão na sociedade antiga, não era um pensamento novo. Nele se detivera Rousseau no fim do XV capítulo do livro III do Contrato social; esse capítulo não escapara a Linguet, que o utilizou nos Annales politiques, civiles et littéraires du dix-huitième siècle. ${ }^{11}$ Um decênio antes, Hume se ocupara amplamente da questão, estudando a população no mundo antigo, e, talvez assustado pelo elevado número de escravos documentado pelas fontes, começara também a deplorável tarefa em que se destacaram muitos modernos historiadores, ou aspirantes a tal: esses, na esteira dele, muito se esforçaram para manipular os números transmitidos pelas fontes antigas sobre a população escrava. Qualquer estudioso de direito romano sabe que a escravidão é tão onipresente na sociedade romana que, para usar a expressão de Fortia, "ela estava por toda a parte ao lado da liberdade": não há norma, não há aspecto da vida social e familiar que não traga à baila a escravidão.

Enfim, nenhuma novidade do ponto de vista dos fatos. A novidade estava alhures. Começava, poucos meses depois da queda de Robespierre, o ataque às "repúblicas antigas" como forma de ataque à república jacobina. E, segundo um cenário depois reproposto e consolidado no curso do século XX em relação ao "comunismo real", a acusação era: vocês não são o que dizem ser. Assim como os mais obstinados e convictos anticomunistas atacaram persistentemente a URSS, deplorando que não fosse um país "verdadeiramente comunista" (e as doléances dos trânsfugas ofereciam a matéria-prima, aceita illico et immediate como verdade revelada), do mesmo modo, em relação à República do ano II o ataque era: essa república é na realidade tirania, e os seus modelos (antigos) eram na realidade ferozes oligarquias. 
Sobre essa história, em que se destacaram pensadores e politólogos liberais que se tornaram retroativamente pontos de referência (Constant, Tocqueville), é preciso fazer um pouco de luz.

É evidente que, mesmo na esteira de uma reflexão começada já antes deles, os demolidores (termidorianos e depois liberais) do "culto" às repúblicas antigas diziam a verdade, e revelavam a verdadeira natureza daquelas repúblicas - mesmo que já não fosse necessário. É claro que eles contribuíram para dar vida a uma imagem realista, verídica e anti-retórica daquelas "repúblicas", e que a ciência histórica deve ser-lhes grata por isso. Essa desmistificação, que volta em algumas admiráveis páginas da Cidade antiga de Max Weber (onde se encontra a celebre definição da antiga democracia como de uma "Gilda" que reparte o espólio), não obteve, porém, todo o sucesso que merecia. E não por culpa de cripto-jacobinos ainda aninhados nos avessos da pesquisa historiográfica, mas porque, por um lado, o classicismo fanático que, bem antes dos jacobinos, idolatrava a realidade antiga e escondia as suas feiúras (por exemplo, a escravidão e a bárbara ferocidade em paz e em guerra) nunca morreu, e, por outro lado, porque a discussão historiográfica do século XIX continuou a tratar a democracia antiga - exaltando-a ou condenando-a - como antecedente imediato e modelo da democracia moderna. George Grote (liberal avançado e admirador de Cleon) e, no outro extremo, Eduard Meyer (que reconhecia na república ateniense do tempo de Cleon todos os males da odiada Terceira República francesa) fizeram um grande trabalho quanto à reconstrução dos fatos, mas mantiveram um nível de compreensão histórica daquela antiga realidade, muito abaixo dos lúcidos diagnósticos de Volney, de Constant, de Tocqueville. E obviamente fizeram escola muito mais do que eles, pela dimensão, autoridade e erudita utilidade de suas monumentais Histórias.

Mas o foco há de ser outro. Naquele laboratório de política que foi a cidade antiga, ou melhor, a civilização política antiga com o seu enorme legado escrito (oratório, filosófico, historiográfico), se desenvolviam conflitos atuais e se expressavam interesses contingentes muito fortes, daquele tempo, daquelas classes sociais; ao mesmo tempo, porém, eram elaborados modelos e conceitos - e aqui está a peculiaridade daquele grande florescimento de cultura política escrita - que acabaram tendo, legitimamente, valor no plano geral: para além do significado concreto que tiveram no seu tempo. Disso vem sua longuíssima, e legítima, "vitalidade". Disso vem o recurso àquela remota matriz por parte de uma élite política, a jacobina, e ainda antes, por parte da "seita filosófica" de seus mestres, Mably e Rousseau. Era a única civilização política conhecida que tivesse produzido uma bagagem ideológico-emotivo-anedótica capaz de transpor os limites temporais e de se colocar ainda como imediatamente útil por causa dos valores gerais (igualdade e liberdade principalmente) que formalizara e concebera: além disso, é evidente que aquele produto intelectual era também o instrumento de auto-representação de uma classe dominante em um determinado período, de uma determinada realidade histórica duramente classista e, analisando bem, profundamente antiigualitária. 
Mas os próprios jacobinos sabiam disso. Ouviram o relatório de Condorcet na Legislativa, onde o maior campeão dos "modernos" denunciara a "corrupção" que os antigos tinham até então introduzido na formação mental dos modernos. Aprovaram um sistema generalizado de ensino público, que gravitava em torno das Écoles Centrales, em que o lugar das línguas clássicas era drasticamente reduzido. O "paradoxo" - por assim dizer - dos jacobinos, que aliás têm méritos muito grandes na formação da Europa moderna, consistiu então na sua indiscutível derivação dos "modernos" (nasceram de uma costela da Encyclopédie), mas, ao mesmo tempo, na sua assunção de uma "ideologia" antiga: o modelo político-virtuoso das repúblicas antigas, em que - e esse é o elemento que mais os fascinava - liberdade e igualdade pareciam ter coexistido, ou, pelo menos (assim lhes parecia), tinham sido apontadas como valores concomitantes e convergentes com igual força e convicção.

Nos meses de governo do Comitê de saúde pública, o estudo do grego (mas também do latim) é reduzido a um nível básico: opta-se pelo conhecimento dos antigos por meio de traduções e paráfrases. (Ainda no relatório de Condorcet, lê-se que "já existem as traduções dos grandes autores".) Porém, ao mesmo tempo, os grandes clássicos (alguns mais, outros menos) e as grandes personagens daquela história monumental são assumidos como portadores de modelos normativos. Sua força residia no seu caráter realmente perceptível como universal, não ligado a uma religião ou a uma seita. É assim que se explica, ou melhor, se entende, aquela evocação das coisas que os gregos disseram e pensaram für ewig. Sua experiência precedia de muito o cristianismo, e afirmava valores que não precisavam daquele suporte, que não eram - assim se poderia vê-los - ligados a um povo, a uma fé, a uma história. Eram os incunábulos de um reconhecimento universal de direitos afirmados como tais. Obviamente se tratava de um uso meta-histórico daquela experiência, cuja recepção e assunção como modelo, no curso dos milênios, favorecera essa fruição meta-histórica. E quanto mais vaga e indefinida era a noção que eles tinham dos antigos, tanto mais esse uso ideológico se tornava possível (e refutável por parte de quem tivesse um maior conhecimento das fontes e dos dados).

Eis por que, além de outros fatores que aqui não é o caso de enumerar, o processo das revoluções anglo-saxãs, por um lado, e francesa, por outro, foi tão diferente. Costumeiramente são postas em relevo outras diferenças: autonomia e direitos individuais naquelas, centralismo e dirigismo jacobino nesta. Mas se prefere deixar oculta a divergência fundamental: aquelas conviveram serenamente com a escravidão, e aliás contribuíram para mantê-la viva (e para libertar-se dela os Estados Unidos tiveram que enfrentar a mais longa e feroz guerra da sua história), essa chegou recta via à noção da nulidade dos "Direitos do homem", se esses estivessem de fato ligados à cor da pele, ou até contemplassem - fora do espaço "europeu" - a possibilidade de manter na escravidão massas de força de trabalho degradada e barata. Aquelas seguiam a Bíblia como fonte de inspiração principal, esta quis extrair da experiência, muito mais antiga e mesmo transfigu- 
rada, dos gregos e dos romanos, o ponto de apoio para uma perspectiva prática de igualdade e liberdade que tivesse objetivos verdadeiramente universais.

Essa "ideologia" bem podia ser desmascarada mediante um conhecimento dos antigos mais sólido e correto. Mas esse era um escamotage muito cômodo para negar a substância daquilo que, por certo de forma arbitrária, os jacobinos estimavam ter alcançado remontando à Antigüidade Clássica. Eles foram os primeiros a abolir a escravidão colonial, e a entender, antes de muitos outros, que a óptica só européia era sinônimo de privilégio, mas o fizeram animados por fantasmas extraídos de uma realidade que se fundava sobre a escravidão.

Havia, porém, um terreno de analogia mais imediata com a política das antigas democracias: a democracia como "violência", como coerção, exercida por parte de um grupo social de não-proprietários (assim era a sanculotterie parisiense) contra as classes privilegiadas e as classes abastadas: que não foram expropriadas, e sim pressionadas, à maneira da "ditadura popular" da Atenas representada com raivosa hostilidade na Constituição dos atenienses. De modo que não se falta à verdade, observando que aqueles que denunciavam a falsa idéia da antiga república, vigente em época jacobina, na realidade não se preocupavam de fato com a dolorosa escravidão, mas sim com o ataque social à riqueza, que a ditadura jacobina estava desferindo: por exemplo, mediante a investigação, grávida de muitas conseqüências, sobre as "riquezas suspeitas". Então esses bem informados termidorianos defendiam de fato a liberdade da riqueza, enquanto trovejavam contra a antiga escravidão, "ocultada” pelos seus adversários.

Quando Hérault de Séchelles, incumbido de redigir a Constituição de 1793, pede ao conservador dos impressos da Bibliothèque Nationale, que the envie com urgência "sur-le-champ les lois de Minos qui doivent se trouver dans un recueil des lois grecques", suscita a ironia de Hippolyte Taine, tanto despropositada quanto facciosa. "A idéia que tivemos da Grécia e de Roma muitas vezes perturbou nossas gerações - escreve Fustel de Coulanges na introdução à Cité antique -: por ter mal observado as instituições da cidade antiga, imaginou-se fazê-las reviver entre nós. Apenas nos iludimos sobre a liberdade dos antigos, e por isso o único resultado foi que a liberdade dos modernos tem sido colocada em perigo"; e acrescenta que o responsável por esse equívoco é o classicismo sem "mediações", típico de um sistema educativo que "nos faz viver desde a infância no meio dos gregos e dos romanos e nos acostuma a compará-los continuamente a nós".

Até a Revolução, toda a cultura e todas as linguagens (políticas também) têm uma base classicista. Mas, depois da Revolução, o classicismo e o progressismo divergem cada vez mais, e uma compreensão mais correta do antigo - como é o caso de Volney, de Constant, de Tocqueville e de Fustel - tende a se afirmar dentro de um horizonte conservador e antidemocrático. Quanto mais recupera os valores elitistas e desigualitários do mundo clássico e da tradição sobrevivente, tanto mais o classicismo europeu ganha em profundidade de compreensão. (Mas o fenômeno da identificação com os antigos se apresentará de forma si- 
métrica: Charles Maurras, inspirando-se em Fustel, se dirá entusiasta de uma "república fundada sobre a escravidão da maioria", e amará por isso se sentir “ateniense”.)

A “recomposição" oficial entre pesquisadores da Antigüidade Clássica e o poder político nascido com a Revolução foi tentada, e parcialmente realizada, por Bonaparte, no quadro da moderada reorganização geral da sociedade francesa como um todo, e do Império.

O documento oficial daquela recomposição, a que aderem todos os classicistas franceses (e europeus), é o Rapport à l'Empereur promovido pelo medíocre e bem relacionado Bon-Joseph Dacier, e lido ao imperador em 1808. Homem-símbolo da operação, e também autor da parte do "Relatório" dedicada à Antigüidade Clássica, foi Ennio Quirino Visconti, que tinha sido o artífice em Roma, com Pio VI, do "Museu Pio-Clementino", e que depois se tornou intelectual cosmopolita e responsável pelas “antigüidades” no Museu do Louvre. E Bonaparte em pessoa naquela ocasião se torna promotor oficial e respeitadíssimo de edições “de Estado” de clássicos gregos, como a grande edição da Geografia de Estrabão, entregue aos cuidados de - entre outros - Adamantios Korais, grego exilado, republicano e naturalizado francês. É bastante claro que o modelo facilmente reconhecível da iniciativa era a "Collection du Louvre" dos autores de história bizantina, promovida na época por Louis XIV. Dessa forma, Ancien Régime e Révolution se reuniam, pelo menos no plano da recuperação da tradição clássica, mas não só.

Não por acaso, apesar da opinião contrária do amigo Volney, é Bonaparte, “espada da revolução”, quem restabelece a escravidão nas colônias.

Em dezembro de 1797, o governo de Victor Hugues em Guadalupe foi desestabilizado por episódios de rebeldia. Por exemplo, na Ilha Marie-Galante, milhares de negros prendiam e desarmavam os brancos, acusados de conspirar com os ingleses, que representavam uma ameaça para a ilha, mas - como é óbvio - principalmente para os negros, que temiam o restabelecimento da escravidão se a ilha caísse de novo nas mãos dos ingleses. Hugues desarmou esses movimentos, mas pouco depois sofreu a maior decepção da sua vida: a de tomar conhecimento sem pré-aviso de ter sido destituído e substituído pelo general Desfournaux, e de ser preso à traição por esse último, receoso de que Hugues permanecesse em todo caso na ilha, mesmo que como simples cidadão.

No dia 18 brumário, muitas coisas começaram a mudar. A delimitação patrimonial do eleitorado, por exemplo, que culminará com o Império e com as tolices da nova "nobreza" inventada pelo imperador, já tinha sido antecipada pelas novidades que o primeiro cônsul, tornando-se cônsul perpétuo, pôs em execução com a ajuda de juristas e ministros de confiança. $\mathrm{O}$ restabelecimento da escravidão em Guadalupe foi sancionado por meio da lei de 20 de maio de 1802, aperfeiçoada pelo ato legislativo de 16 de julho do mesmo ano. Não é irrelevante lembrar que Fouché, ministro do Interior de Bonaparte, tinha consi- 
deráveis propriedades nas colônias. É muito significativo que, quase no mesmo período, iniciasse a liquidação, em Santo Domingo, do leader negro ToussaintLouverture (preso no dia 12 de junho de 1802), que aliás fora leal administrador das rendas que Josephine Beauhornais tinha na ilha. Toussaint será executado, sem direito a defesa, no ano seguinte, com a ridícula e ao mesmo tempo infamante acusação de "acordo com os ingleses"!

O texto do ato legislativo que restabelecia a escravidão em Guadalupe é muito instrutivo como exemplo de manipulação colonialista da história:

Considerando que, em conseqüência da Revolução e de uma guerra extraordinária, foram introduzidos nos nomes e nas coisas deste país alguns abusos subversivos da segurança e da prosperidade de uma colônia;

Considerando que as colônias não são outra coisa senão comunidades formadas pelos europeus, que trouxeram uns negros como os únicos indivíduos aptos à exploração deste país; que, entre essas duas categorias fundamentais de colonos e negros, se formaram umas raças de mestiços ainda assim distintos dos brancos, que deram vida às comunidades;

Considerando que somente esses são os indígenas da nação francesa e devem exercer as suas prerrogativas;

Considerando que os benefícios concedidos pela mãe-pátria, no estabelecimento das normas essenciais destas comunidades, só serviram para desnaturar todos os elementos da sua existência, e para induzir progressivamente esta conspiração geral, que explodiu nesta colônia contra os Brancos e as tropas enviadas às ordens do general pelo governo consular, enquanto as outras colônias, submetidas a este regime familiar e paternal, ofereciam a imagem da abastança de todas as categorias de homens, em contradição com a vagabundagem, a preguiça, a miséria e todos os males que oprimiram esta colônia, e especialmente os negros abandonados a si mesmos; por isso a justiça nacional e a humanidade impõem, tanto quanto a política, a volta dos verdadeiros princípios em que assentam a segurança e os sucessos das comunidades constituídas pelos franceses nesta colônia, no momento em que o Governo eliminará com energia os abusos e os excessos que se manifestaram no passado e ainda poderiam emergir novamente...

E eis o artigo $1^{\circ}$ :

Até nova ordem, o título de cidadão francês no território desta colônia e dependências será exclusividade dos Brancos. Nenhum outro indivíduo poderá receber este título e nem exercer as funções ou os usos a este relacionados. ${ }^{12}$

No dia 2 de julho foi proibido aos negros o acesso ao território metropolitano. No dia 19 de fevereiro, uma nova medida proibia que os oficiais de estado civil legalizassem casamentos entre brancos e negros.

A decadência da ilha do ponto de vista cultural e sanitário, a partir daquele momento, foi irrefreável. Nem se descuidou, obviamente, de expurgar de vez o exército em detrimento dos elementos agora "indesejáveis".

Constantin-Francois Volney, que por várias razões tinha merecida fama de "independente" em relação ao imperador, tentou impedir esse - na visão 
dele - desvio dos princípios sancionados pela Revolução. Ele era um homem impregnado de cultura "enciclopedista", mas tinha também visitado a América pessoalmente; e talvez isso valha mais ainda. Nos Estados Unidos, ele assistira ao confronto entre dois "partidos", o filofrancês e o filoinglês, e também observara como a situação nas Antilhas interferia nessa tensão.

Depois do seu regresso da América, Volney se tornou íntimo de Bonaparte. O seu laicismo anti-religioso, perfeitamente iluminista, tornava-lhe inaceitável aproximar-se da Igreja Católica e da Concordata; a sua forma mentis republicana tornava-lhe repugnante a idéia de proclamar um Império. Por causa dessa sua independência, já perdera a chance de ascender ao Consulado junto com Bonaparte. Isso, porém, não impediu que o pragmático imperador o obrigasse a aceitar, sucessivamente, um lugar no Senado, o papel de "Commandeur de la Légion d'Honneur" e, por fim, até o título de conde do Império. O imperador ia firmemente pelo caminho do triunfo burguês: triunfo cujos pilares eram tanto a liquidação do sufrágio universal quanto o restabelecimento da escravidão colonial (modelo inglês). Volney era uma espécie de nota desafinada: preso na contradição, que logo explodiu em toda sua clareza, entre o valor universal (e por isso mesmo muito "incômodo") dos princípios de 1789, e a prática real de domínio da classe finalmente dona da situação. Uma classe de modos bruscos e sem desejo algum de submeter-se ainda aos princípios universais, a que muitos nobres (depois ex-nobres), aliás, tinham aderido individualmente, na aurora, grávida de futuro, da ruptura histórica de 1789.

É claro então que os gigantescos "pupi" greco-romanos do repertório oratório e emotivo dos políticos jacobinos já não podiam permanecer.

$\mathrm{Na}$ realidade, a "máscara" antiga desses modernos revolucionários não era natural. Banalizando uma famosa expressão de Marx, Edward Hallet Carr definiu o classicismo na cultura política dos jacobinos como "uma componente anômala". ${ }^{13}$ No capítulo 6 da Sagrada família, Marx e Engels detectavam a contradição do "classicismo" jacobino:

Ter de reconhecer e sancionar, nos Direitos do Homem, a sociedade burguesa moderna, a sociedade da indústria, da concorrência generalizada, dos interesses privados que perseguem livremente seus fins, da anarquia, do individualismo natural e espiritual, completamente alienado; e ao mesmo tempo querer anular de uma vez, para os indivíduos, as manifestações vitais desta sociedade, requerendo formar à maneira antiga a cabeça política desta sociedade: que ilusão colossal! $\mathrm{O}$ momento emblemático dessa trágica ilusão é o dia em que Saint-Just, na hora da sua execução, aponta para a grande tábua dos "Direitos do Homem" pendurada no salão da Conciergerie e exclama com orgulho: E mesmo assim sou eu o autor disso! Esta tábua proclama, precisamente, o direito de um homem que já não pode ser o homem da sociedade antiga, do mesmo modo que as condições econômicas e industriais em que vive não são as da antignidade. É sob o Diretório que a sociedade burguesa irrompe irrefreavelmente - sociedade que a própria Revolução libertara das amarras feudais e reconhecera oficialmente, por mais que o Terror tentasse sacrificá-la a uma concepção antiga da vida política. ${ }^{14}$ 


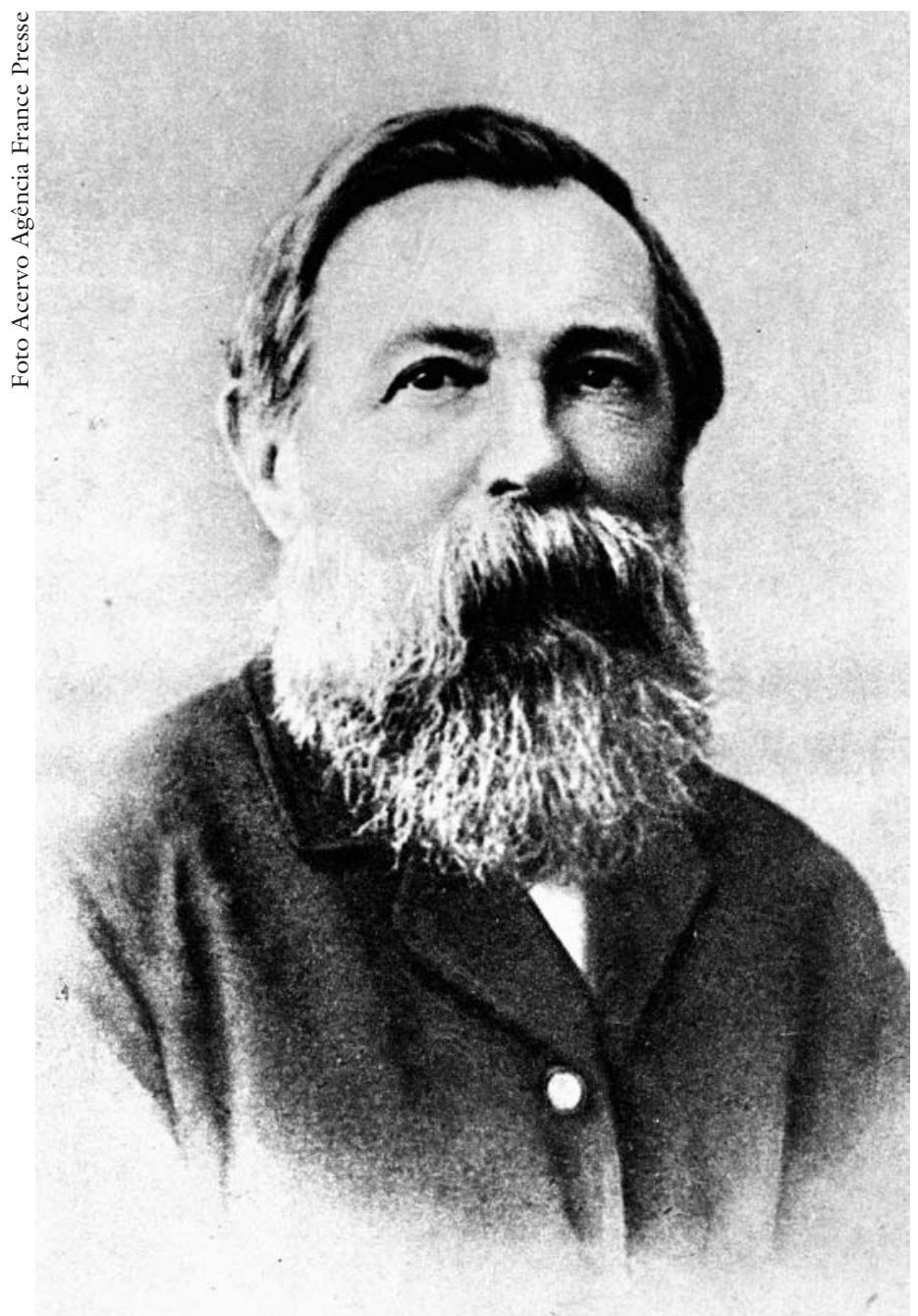

Friedrich Engels (1820-1895), teórico socialista alemão.

Marx e Engels detectam justo na breve "coerção" do "Terror" o máximo esforço para realizar concretamente a "democracia antiga". Com o fim do predomínio jacobino, o repertório romano é abandonado: "Uma vez estabelecida a nova formação social - escreve Marx no 18 Brumário de Luís Bonaparte (1852) - desapareceram os colossos antediluvianos, e, com eles, o mundo romano ressuscitado". ${ }^{15}$ Muito em breve, os eventos fundamentais da Revolução (suas etapas, suas acelerações, suas quedas, suas derrotas) e as alianças formadas naquele decênio, que vai de 1789 ao 18 brumário, constituirão por sua vez os novos mitos e a nova linguagem.

\section{Notas}

1 Disponíveis na tradução italiana de Marco Rivelli (Putney: alle radici della democrazia moderna. Il dibattito tra i protagonisti della "Rivoluzione inglese". Milano: Baldini \& Castoldi, 1997). 
2 Sobre a presença das "repúblicas antigas" na cultura política inglesa daquele período, A. M. Strumia, Autorità e potere: le repubbliche antiche nell'Inghilterra del XVII secolo, em I linguaggi politici delle rivoluzioni in Europa XVII-XIX secolo. Atti del convegno (Lecce, 11-13 ottobre 1990), por E. Pii, Leo S. Olschki, Firenze 1992, p.67-74.

3 Putney, cit., tradução italiana de Revelli, p.75.

4 La formazione degli Stati Uniti d'America, v.I, por A. Aquarone, C. Negri, C. Scelba, Nistri-Lischi, Pisa 1961, p.70; 114-15; 121.

5 R. Dahl, How Democratic is the American Constitution? New Haven-London: Yale Univ. Press, 2001.

$6 \mathrm{O}$ relatório da memorável sessão é reconstruído em Archives Parlementaires de 1787 à 1860, I série (1787-1799), tome 84, CNRS, Paris 1962, p.276-83.

7 H. Bangou. La Guadeloupe, I: 1492-1848 ou l'Histoire de la colonisation de l'île. Paris: L'Harmattan, 1987. p.122.

8 Ver E. Burgos, Mi chiamo Rigoberta Menchú (1983), tradução italiana, Giunti, Firenze 1987, p.164. Sobre o jesuíta Vieira, fundamentais são os estudos de Alfredo Bosi, em Dialética da colonização. São Paulo: Companhia das Letras, 1992.

9 É o caso do émigré Laluzerne, que traduz e comenta o panfleto em Londres em 1793.

10 L'École Normale de l'an III. Leçons d'histoire, de géographie, d'économie politique. Édition annotée des cours de Volney, Buache de La Neuville, Mentelle et Vandermonde, por A. Alcouffe, G. Israel, B. Jobert, G. Jorland, F. Labourie, D. Nordman, J.-C. Perrot, D. Woronoff. Paris: Dunod, 1994. p.111-2.

11 Volume I, London 1777, nota da p.107.

12 Bangou, La Guadeloupe, I, cit., p.180.

13 E. H. Carr. 1917: Before and After. London, 1969.

14 Marx-Engels-Werke. Berlin: Dietz Verlag, 1959. II, p.129-30.

15 Ibidem, VIII, p.116.

RESUMO - O ENSAIO examina os modos pelos quais os movimentos revolucionários da Idade Moderna interpretaram as expressões "democracia grega" e "democracia ateniense". A análise dos documentos antigos prova que o regime social de Atenas se fundava na escravidão. A República e o Império romanos não praticaram a democracia na acepção que o termo tem hoje. Apesar dessas diferenças semânticas, os mitos da "democracia grega" e das "liberdades republicanas de Roma" serviram à ideologia dos jacobinos para propor políticas de igualdade e liberdade entre os cidadãos. O ensaio aponta também o convívio íntimo de liberalismo e escravidão na Inglaterra dos fins do século XVIII e na França pós-1789.

PALAVRAS-CHAVE: História Antiga, História política, Grécia, Democracia.

ABSTRACT - THIS PAPER examines how Modern revolutionary movements interpreted the expressions "Greek democracy" and "Athenian democracy". Analyses of ancient documents prove that Athens' social regime was founded upon slavery. Neither did the Roman Republic and the Roman Empire did not practice democracy, as we understand the term today. In spite of these semantic differences, the myths of "Greek democracy" 
and "Rome's republican freedoms" were useful to the Jacobins' ideology that propounded policies of equality and freedom for all citizens. The essay also brings up the intimate relationship between liberalism and slavery in late 18th century England and in post-1789 France.

KEYWORDS: Ancient history, Political history, Greece, Democracy.

Luciano Canfora é professor de Filosofia Clássica na Universidade de Bari e coordena o Centro de Estudos Históricos da Universidade de San Marino. É autor, entre outras obras, de Tucidide e l'Impero (Laterza, 2000); Storia della Letteratura Greca (2001); Critica della retorica democratica (2002); Giulio Cesare. Il dittatore democratico (2004). Algumas obras do autor publicadas no Brasil: Júlio César o ditador democrático (Estação Liberdade, 2002), Livro e liberdade (Casa da Palavra, 2003), A biblioteca desaparecida (Cia. das Letras, $4^{\underline{a}}$ ed. 1988).

O texto aqui publicado é a tradução de um capítulo de La democrazia. Storia de un' ideologia (Laterza, 2004).

Tradução de Enrico Lippolis. O original em italiano encontra-se à disposição do leitor no IEA-USP para eventual consulta. 